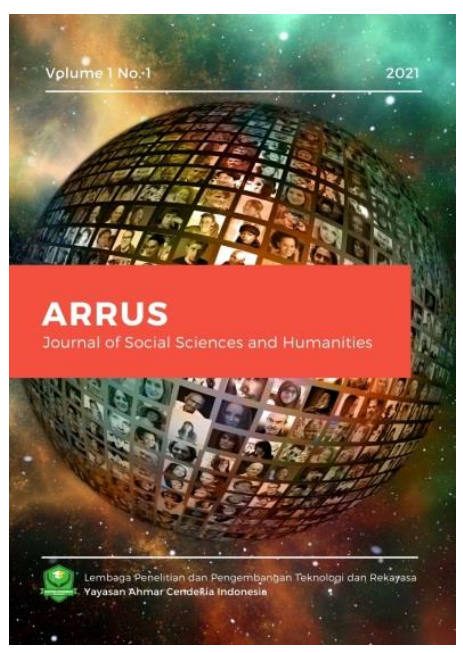

${ }^{*}$ Corresponding author: Raghu Bir Bista, Department of Economics, Tribhuvan University, Nepal

E-mail: bistanepal@gmail.com

RESEARCH ARTICLE

\title{
Economics of Community-Based Disaster Management and Household Participation: Evidence of The Western Nepal
}

\author{
Raghu Bir Bista \\ Department of Economics, Tribhuvan University, Nepal
}

\begin{abstract}
This paper examines households' participation in community-based disaster management in western Nepal based on the secondary and primary data sets under the framework of explorative and descriptive statistics. As a result of the study, multi-hazards occurred. Out of these multi-hazards, the catchment areas and the community were disaster-prone by flood and landslide more than other hazards: insects, drought, animals, etc. in terms of severity and frequency. Further, the community-based disaster management that was proactive and participatory to assess disasters, hazard locations, and their impacts made stakeholders to the community for their participation, ownership, and resilience. In community-based disaster management, the household was actively participatory not only in pre-disaster, disaster, and post-disaster focusing on preparedness and planning more than rescue and reconstruction, rehabilitation, and recovery. Its economic cost is 78 mean days per household. It is 21 percent of a year (365 days) calendar. Its mean wage income loss is 39000 Nepali Rupees (330 USD) per annum that is 30 percent of 1071 USD per capita. Thus, the rural household has a significant economic cost of CBDMG activity to be resilient from multi natural hazards. However, it can reduce multi times the disastrous cost to them. Its outcome may not be positive to household income, welfare, and poverty reduction. Thus, the community-based disaster management approach is effective was in terms of less time, fewer resources but the quick response.
\end{abstract}

Keywords: community resilience, natural disasters, rescue, alert system, local government, Nepal, etc.

\section{Introduction}

Over many decades, disaster is the so-called natural cut-off measure to balance natural phenomena with unpredictable and undesired natural events including earthquakes, floods, landslides, fire, drought, viruses, etc. These events have their cycles per annum, except the earth quake's cycle. Each cycle of these disaster events has negatively interacted with human-induced activity- life, settlement, infrastructure, and different production activities and natural structure and environment. Let's examine the flood. We can get its destructive records of the 14th century in the World. It may be before the 14th century. Similar records can be found in all disasters. In Nepal, its multiple hazards and its losses are recorded as follows: heavy rainfall, flood, landslides, fire, drought, windstorm, animal incidents, glacier melting, etc.(MoHA, 2020). Therefore, multiple hazards are key challenges in the World. 
Disaster has a huge economic loss having social cost to the World. The United Nations Environment Program (UNEP) (2003) argues it as shock's consequences including loss of human lives, malnutrition, income losses, water stress, and environmental degradation.

Its evidence is 520 USD billion economic losses that are 0.6 percent of the World's GDP and its social cost was 26 million people into poverty (WB, 2016). In addition, about 219 natural disaster events made 16 million USD economic losses and destroyed millions of homes, along with livelihood crises and diseases in Bangladesh (IEDRO, 2010). In 2009, tropical cyclone Alia had an economic cost of 0.5 million death, a half million people displaced, and destruction of half a million houses and hundreds of thousands cropland destruction death toll at 500,000 people, making it the deadliest tropical storm in recorded history (IEDRO, 2010). It remembered the flood 2004 on the Ganges, Brahmaputra, Jamuna, and Meghna and its economic loss of 30 million people and submerged $40 \%$ of Bangladesh's capital, Dhaka. Similarly, in Nepal, the economic loss of the earthquake in 2015 was 700 billion USD and 8500 death tolls (MOHA, 2020). Annual economic loss is about 0.2 billion rupees (16.6 million USD) and displacement of more than a million households (MOHA, 2020). As a result, multiple hazards have a huge economic to national economy and social cost to the community not only in the World but also in Nepal. Therefore, disaster risk reduction and management (DRRM) are most relevant to the World and also to Nepal.

Based on literature and observations, there are two popular approaches in disaster management: adaptation and mitigation in recent years to natural disasters, and humaninduced disasters respectively (IPCC, 2001; Stern, 2006; \& UNFCC, 2008). The World community has been implementing adaptation approaches in different disaster preventive and rescue activities at the national and local level on the various scale and programs all over the World. We have different initiation at the national level. For example, Koshi Barrage was constructed in 1962s (MoE, 2020). Its major objective was to control the Koshi flood and its destruction in Bihar, India, along with irrigation and hydropower (Bista, 2016). Similar initiation can be found all over the World. Similarly, at the local level, the community and the local government have also initiated formally and informally based on natural disastrous events.

Over some decades, community-based disaster management (CBDM) has become a popular sustainable and stakeholder-based measure in the World for disaster risk reduction (DRR), although national level disaster management is effective. Its wider application and practices indicate a paradigm shift in disaster management at international policy and strategy (UNISDR, 2005). UNISDR (2005) focuses on local-level actions to reduce disaster risks. It is supplemented by the Hyogo Framework for Action (2005-2015). The framework argues the need for local and national institutional initiation to manage disasters on disaster risk assessment, early warning systems, community resilience capacity, hazard reduction, and preparedness (UNISDR, 2005). Literatures (Arnstein, 1969; Bista, 2018; Bista, 2019; Bista 2020; Haque \& Uddin, 2013; Jahangiri, Izadhah \& Tabibi, 2011; Khan \& Rahman, 2007; Slaymaker \& Christiansen, 2005; UNISDR, 2004 and Victoria, 2003) mention CBDM approach for vulnerability assessment capacity building of local community, developing adaptation capacity of the local community to be resilient, thinking alternative strategies and resources for adaptation and mitigation at the community level and life skill development for rescue, relief, reconstruction, rehabilitation and recovery of the vulnerable population, along with developing proactive of the local community in disaster risk reduction and management. It is simplified by Yodmani (2001) by explaining $\mathrm{CBDM}$ as the approach of minimizing vulnerabilities and fortifies the people's capacity with objectives: a) minimizing vulnerabilities and enhancing the capacity of vulnerable groups and communities to minimize loss and damage of life and property, b) reducing human stress and loss and c) fast recovery.

CBDM has key elements and features. Shaw (2012) and Victoria (2002) provide CBDM's elements and features as follows: a) people's participation, b) priority to the most vulnerable 
groups, families, and the community, c) community-specific risk reduction, d) identified capacity and coping mechanism, e) integrity between development and disaster risk reduction, f) facilitating role of outsiders. The literature argues the need for CBDRM to reduce disaster risk reduction and management. Shaw (2012a) and Ishiwatari (2012) argue local community's concern for disaster risk reduction more than others. Izumi \& Shaw (2012) and OXFAM (2012) find CBDRM is time-efficient and cost-effective. In other words, this literature believes that the capacity of the local community will increase their proactive and ownership and reduce response time to disaster risk. Furthermore, Sjostedt and Sturegard(2015) mention three pillars: participation, sustainability, and ownership for its justification. Therefore, CBDRM is relevant to disaster risk reduction and management.

Empirically, Pandey \& Okazaki (2005) assessed Community based Disaster Management: Empowering Communities to Cope with Disaster Risks based on the case method. The study found CBDM as a component of sustainable development to prevent natural disaster risks. It included activities: the improvement of the safety levels of core community facilities such as schools; the dissemination of best practices in disaster risk management at the community level; and the formulation of integrated programs for sustainable development through disaster risk management initiatives. Its lesson learned is a) Community empowerment and communication help to achieve sustainability in CBDM; b) Community based action plans and training improves the community's problem-solving skills; c) Transparency of activities and dissemination of knowledge and information encourage people's participation in activities; d) CBDM efforts need stable financial resources and e) Institutionalizing the community and the private sectors can result in more sustainable disaster management program.

Similarly, Sjostedt and Sturegard (2015) conducted a study on the implementation of community-based disaster risk management in the Mekong Delta, Vietnam based on primary information and data. Its objectives were what are the mode and modalities through which citizens and communities in the Mekong Delta region in Vietnam are involved in disaster risk management and how to do CBDRM impacts risk reduction for the communities. The study found CBDRM as an effective approach for DRR in the Mekong Delta and its modes and modalities as best to deal with the threats of disasters. It argued it was an exemplary work. Additionally, Huq(2016) examined Community based Disaster Management Strategy in Bangladesh: Present status, prospects, and challenges in Bangladesh based on secondary data and information. In CBDRM, the study found activities: the creation of public awareness, proper utilization of climate information, appropriate prevention and mitigation measures, showing mutual respect, timely communication, and regular basis specialized training.

Furthermore, Lassa, Boli, Nakmofa, Farggide, Ofong, and Leonis (2018) studied Twenty years of community-based disaster risk reduction experience from a dryland village in Indonesia by using longitudinal observations and qualitative and quantitative methods during 1999-2017, along with field observation. Its result is the rise and fall of a community responding to disaster risks over time. Empirically, Azad, Uddin, Zaman, \& Ashraf (2019) examined the national disaster management policy initiatives in Bangladesh as communitybased approaches at the local level and developed cross-scale partnerships to reduce disaster risk and vulnerability based on secondary and primary data collected from two coastal communities in Kalapara Upazila in Patuakhali District. The study found the critical role of community-based disaster preparedness activities in developing their adaptive capacity and resilience to disasters and the need of policy and research for a closer examination of the dynamics of community-based disaster management, the role of locallevel institutions and community organizations in partnerships and resilience building for successful disaster management. Above theoretical and empirical literature have focused on the CBDM, its issues, and lesson learned.

Despite focusing on community-based disaster management in the national disaster management act and policy and community-based disaster management initiation at a local 
level, none of the literature has covered the community-based disaster management approach at the local community level. Therefore, this study is highly relevant to fill the above literature gaps related to community-based disaster management to cope with natural disasters and their adverse effects. Its output will be a valuable input to local and national disaster management policy and activities.

\section{Objectives}

This study was to assess the effectiveness of a community-based disaster management approach in the Sot Khola catchment areas: Gadhi, Lekhagaon, and Kunathari. Its specific objectives were a) identifying natural hazards and their intensity in the study areas, b) assessing households' participation in community-based disaster management, and d) identifying issues in the implementation of community-based disaster management.

\section{Research Method}

\subsection{Conceptual Framework}

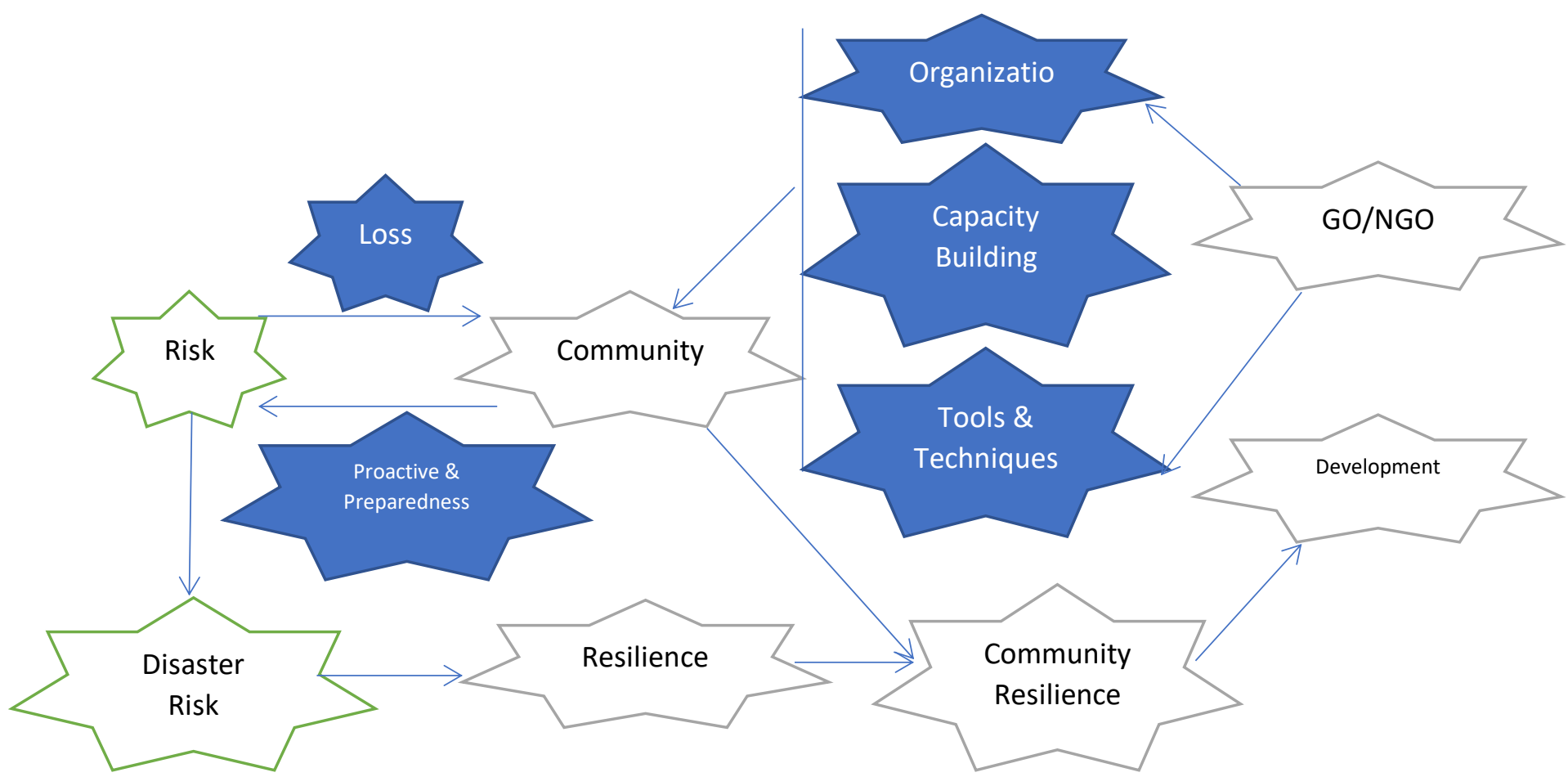

Figure 1: Conceptual Framework

Let's assume the community and disaster has a negative relationship in which multi-hazards (flood, landslides, heavy rainfall, drought, cold wave, earthquake, etc.) affect adversely the community in terms of economic loss, loss of assets, loss of house, death, injury, loss of food grains, etc. As a result, the community is vulnerable.

By Community based Disaster Management (CBDM), the local government and NonGovernment Organization (NGOs) have initiated to form vulnerable community groups in the catchment areas, to conduct capacity-building programs for the vulnerable community groups, and to equip tools and techniques to the vulnerable community. As a result, the community owns disaster as the stakeholder. They are proactive to identify disaster's nature, type, and intensity over time and brainstorming alternative preventive measures for preparedness and planning. Thus, the community can reduce disaster risk and economic loss, and causalities for development and happiness. 


\subsection{Study Area}

The study area that was undertaken this study is Sotkhola Water basin Catchment Areas: Gadhi, Lekhagaon, and Kunathari (Figure 1) located in the northern part of Surkhet, western Nepal. The Sotkhola is a tributary of a big river, Bheri (Figure 1) is about $30 \mathrm{~km}$ long originated from the upstream, Chandane, Gadhi VDC and ends downstream, Rakseni, Kunathari VDC (Figure 1)(DDC, 2015). It is a small stream but the observation of its water level in both seasons: summer and winter show consistent level, except monsoon rain fed flooding water level. Its permanent character establishes its glacier source. Thus, the river is a monsoon lover.

It is a beautiful geomorphological of the study area comprised of mainly three catchment areas: Gadhi VDC (upper stream), Lekhagaon VDC (middle stream), and Kunathari VDC (downstream) located in different three altitudes (DDC, 2015). The catchment areas cover from the Sea level to the Mahabharata range. This landscape diversity including hill and mountainous landscape is a habitat of wildlife and aquatic and terrestrial ecosystem, along with heterogeneous caste and communities. This water basin is a source of clean drinking water, irrigation water and water, and terrestrial ecosystems to the catchment households.

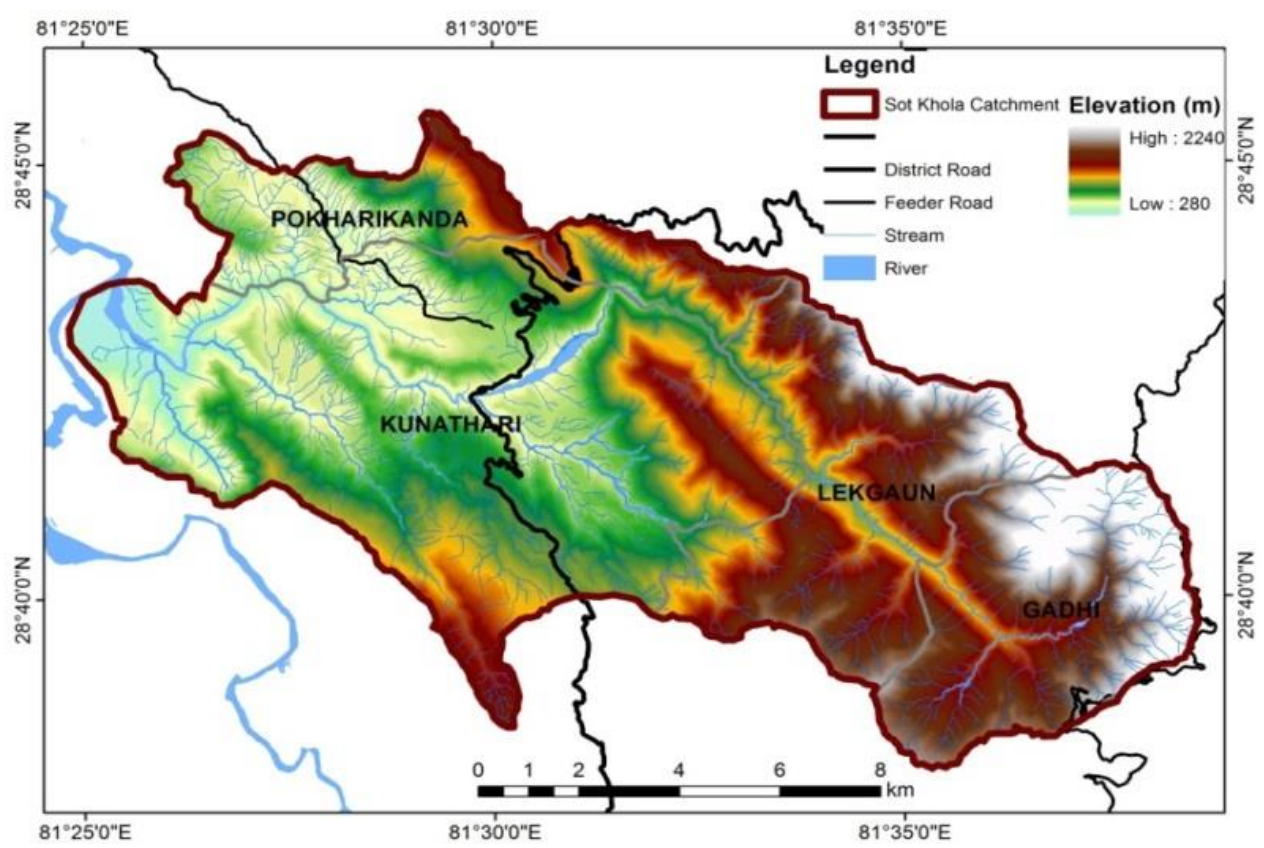

Figure 2: Sotkhola and its catchment study Area

Source: GIS map of Study area based on field survey, 2015

Gadhi is the upper stream catchment area of the study area located at the altitude of 1200 meters in the Mahabharata Range (Figure-1). This rugged village that was only 28 square $\mathrm{km}$ landscape was only about $9 \mathrm{~km}$ far north from District headquarter, Surkhet. In the population census 2011, the population size of this small village was 3369. Interestingly, the demographic size was divergent castes with Magar (37.7 percent), Brahmin (30.6 percent), Cheetri (17.1 percent), Sunwar (5.7 percent), and others (22.6 percent). Others included Kami, Sarki, Thakuri, Gurung, Damai, Sherpa, etc. (VDC, 2015). Lekhgaon village spreads $110 \mathrm{~km}$ length and $30 \mathrm{~km}$ breadth of 2451 square $\mathrm{km}$ (249016 hectares) from 198 meters (Tata pani) to 2369-meter (Matela gurase) altitude (Figure 1). Hill with 84 percent dominates to 16 percent valley. The population size was 3999 (651 households) (DDC, 2015). c) Kunathari is another study village lying between 600 meters and 1200 meters (Figure 1). It is $20 \mathrm{~km}$ far from district headquarter). Population size was 3413 (CBS, 1991) and (DDC, 2015). 
This study area was purposively selected with the following rationales: i) its record-breaking climatic variation and disasters event as flooding and landslides in 2014, ii) its huge risk and vulnerability at the catchment areas, iii) its morphological structural change, iv) its aquatic and terrestrial ecosystem and biodiversity loss, v) it's agricultural land and crop loss and its risk and vi) active of Community Based Disaster Management (CBDM) in the catchment areas.

\subsection{Data and Data Collection Method}

The research design of this study was explorative cum descriptive based on quantitative and qualitative data. For quantitative and qualitative data, there were employed secondary and primary sources. Firstly, the secondary data sets were related to climate shock-induced flood and landslides disaster and household vulnerability collected from District Development Committee (DDC) office as well as from the Ministry of Home, along with the primary data sets related to household socioeconomic information collected from the household survey conducted in the post-natural disasters in 2014 during from September 2015 to October 2015 to collect reliable and accurate data and information about climatic events and disasters and its vulnerability to install hydrological monitoring system, alert system, infrastructure, and building adaptation capacity. As a supplementary tool, the Key Informant Interview (KII) was employed.

The household survey was designed into a two-stage sampling method: cluster and random sampling method. In the first stage sampling method, the cluster method was used by dividing nine clusters based on altitude, location, and place covering 3310 households over the catchment areas: Gadhi, Lekhagaon, and Kunathari. Similarly, in the second stage sampling method, 642 household samples $(19.3 \%)$ were randomly selected by using a random sampling method from nine clusters.

In the survey, the structural questionnaire was its tool to survey 642 sample households to collect socio-economic information about the household (land holding, income level, source of income, size of family, gender, age, caste, etc.), climatic events, and vulnerability and communitybased disaster management group and their adaptation and mitigation measures.

\section{Community Based Disaster Management and Natural Hazards}

As mentioned in National Disaster Act and Policy 2019 and Disaster (Relief) Act 1983 and the Local Governance Act 1988, the Disaster Management approach has been localized and decentralized to meet Hyogo Framework for Action (2005-2015). At present moment, its authority is devolved fully to local bodies: Metropolitan city, Municipality, and Rural Municipality, although Prime Minister Level and District Level Disaster Rescue Committee are also in this regard. This top-to-bottom-level approach is also effective but its output and outcomes are not as expected at the community level. Its consequence is generally unsatisfactorily. Therefore, as an alternative, a community-based disaster management approach has been experimental at the community level.

The community-based disaster management approach has the idea of local ownership, local participation, and local response to minimize disaster and its risk, along with participatory disaster assessment and management. In the study area, there was the practice of community-based disaster management in the different disaster-prone areas of three catchment areas: Gadhi, Lekhagaon, and Kunathari. About 6 community groups were active. The group was comprised of a caste and gender balance approach. In other words, its criteria were disaster-prone households-based.

Table 1 shows details of Community-based Disaster Management Interventions in which there were two international organizations: the Red Cross and OXFAM facilitating to execution of four interventions. Its beautiful process was to make institution building to 
the community with specific objectives of disaster management and to develop the participatory method.

The community was sensitized about the disaster to be the stakeholders for ownership, participation, and opinion, along with capacity building and tools and techniques. Thus, the community was technically and financially empowered against disaster.

Table 1: Intervention of Community Based Disaster Management Group

\begin{tabular}{|c|c|c|}
\hline Intervention & Activities & Details \\
\hline Intervention I & $\begin{array}{l}\text { Community } \\
\text { Group }\end{array}$ & $\begin{array}{l}\text { Red Cross and OXFAM formed } 25 \text { members community group to } \\
\text { minimize natural disasters and their risk and to make the } \\
\text { community a Stakeholder of disaster for their participation and } \\
\text { ownership. }\end{array}$ \\
\hline $\begin{array}{c}\text { Intervention } \\
\quad \text { II }\end{array}$ & $\begin{array}{l}\text { Awareness \& } \\
\text { Sensitization }\end{array}$ & $\begin{array}{l}\text { Red Cross and OXFAM provided awareness and sensitization } \\
\text { programs about natural hazards and their merits and demerits and } \\
\text { alternative measures. }\end{array}$ \\
\hline $\begin{array}{c}\text { Intervention } \\
\text { III }\end{array}$ & $\begin{array}{c}\text { Capacity Building } \\
\text { Training }\end{array}$ & $\begin{array}{l}\text { Training Program was conducted to improve their capacity of } \\
\text { assessment method and participatory planning and preparedness } \\
\text { to identify natural hazards and to assess natural hazards, along with } \\
\text { to develop the adaptive plan. }\end{array}$ \\
\hline $\begin{array}{l}\text { Intervention } \\
\text { IV }\end{array}$ & $\begin{array}{l}\text { Tools and } \\
\text { Techniques }\end{array}$ & $\begin{array}{l}\text { These organizations provided rescue tools and techniques to the } \\
\text { community group so that they could rescue as soon as possible } \\
\text { efficiently. }\end{array}$ \\
\hline
\end{tabular}

Table 2 shows CBDM actions. About 6 community groups with stakeholdership, ownership, and participation had initiated six major actions: a) hazard map, b) planning, c) alert system, d) preventive construction, e) awareness program, and f) emergency response and place. Its outcomes were participatory proactive and preparedness to reduce disaster risk towards community resilience.

Table 2: CBDM action

\begin{tabular}{|c|c|c|c|c|}
\hline $\begin{array}{l}\text { CBDMG } \\
\text { action }\end{array}$ & Activities & Details & Output & Outcomes \\
\hline $\begin{array}{c}\text { Action } \\
\text { I }\end{array}$ & Hazard Map & $\begin{array}{l}\text { Community Group had } \\
\text { made hazard map of the } \\
\text { community in the } \\
\text { participation of } \\
\text { household. }\end{array}$ & $\begin{array}{l}\text { Major and minor } \\
\text { natural hazards } \\
\text { were included } \\
\text { across the Ward } \\
\text { level. }\end{array}$ & $\begin{array}{c}\text { Awareness, } \\
\text { Ownership, and } \\
\text { Alert }\end{array}$ \\
\hline $\begin{array}{l}\text { Action } \\
\text { II }\end{array}$ & Planning & $\begin{array}{l}\text { Based on the hazard map, } \\
\text { participatory planning was } \\
\text { formulated for minor and } \\
\text { major natural hazards. }\end{array}$ & $\begin{array}{l}\text { Action Plan was } \\
\text { formulated to } \\
\text { minor and major } \\
\text { natural hazards by } \\
\text { period. }\end{array}$ & $\begin{array}{c}\text { Awareness and } \\
\text { Preparedness }\end{array}$ \\
\hline $\begin{array}{l}\text { Action } \\
\text { III }\end{array}$ & Alert System & $\begin{array}{c}\text { The rainfall measurement } \\
\text { plan was executed by } \\
\text { allocating its } \\
\text { responsibility. A Mobile } \\
\text { and FM radio alert system } \\
\text { was made. }\end{array}$ & Alert system & $\begin{array}{l}\text { Information } \\
\text { and } \\
\text { communication } \\
\text { among } \\
\text { community } \\
\text { group }\end{array}$ \\
\hline $\begin{array}{l}\text { Action } \\
\text { IV }\end{array}$ & $\begin{array}{l}\text { Preventive } \\
\text { Construction }\end{array}$ & $\begin{array}{l}\text { Wall and Plantation } \\
\text { programs were considered } \\
\text { as preventive measures. }\end{array}$ & $\begin{array}{l}\text { Prevention to } \\
\text { flood and } \\
\text { landslides }\end{array}$ & $\begin{array}{l}\text { The barrier for } \\
\text { flood and } \\
\text { landslides }\end{array}$ \\
\hline $\begin{array}{l}\text { Action } \\
\mathrm{V}\end{array}$ & $\begin{array}{l}\text { Awareness } \\
\text { Program }\end{array}$ & $\begin{array}{l}\text { The mass awareness } \\
\text { program was initiated at }\end{array}$ & Awareness to all & $\begin{array}{c}\text { Improving } \\
\text { ownership and }\end{array}$ \\
\hline
\end{tabular}




\begin{tabular}{|c|c|c|c|c|}
\hline $\begin{array}{l}\text { CBDMG } \\
\text { action }\end{array}$ & Activities & Details & Output & Outcomes \\
\hline & & $\begin{array}{c}\text { the mass level through } \\
\text { School Program, Drama, } \\
\text { and Pamphlet. }\end{array}$ & & $\begin{array}{c}\text { massive } \\
\text { participation in } \\
\text { preparedness, } \\
\text { rescue, and } \\
\text { recovery }\end{array}$ \\
\hline $\begin{array}{l}\text { Action } \\
\text { VI }\end{array}$ & $\begin{array}{c}\text { Emergency } \\
\text { Response and } \\
\text { Place }\end{array}$ & $\begin{array}{l}\text { An emergency response } \\
\text { strategy was formulated. }\end{array}$ & $\begin{array}{c}\text { Active } \\
\text { participation and } \\
\text { contribution }\end{array}$ & $\begin{array}{l}\text { Fast rescue, } \\
\text { relief, and } \\
\text { recovery }\end{array}$ \\
\hline
\end{tabular}

As the output of CBDM Group, natural hazards were identified in the catchment areas: Gadhi, Lekhagaon, and Kunathari. Table 3 shows natural hazards and their impacts identified by the participatory approach by the CBDM group. In the study area, there were identified as the following natural hazards: flood, landslide, hail \& storm, insect, animals, drought, cold wave, and snakes.

Table 3: Natural Hazards and Its Impacts

\begin{tabular}{llllccccc}
\hline \multicolumn{1}{c}{ Description } & Flood & Landslide & $\begin{array}{c}\text { Hail \& } \\
\text { Storm }\end{array}$ & Insect & Animals & Drought & $\begin{array}{c}\text { Cold } \\
\text { wave }\end{array}$ & Snakes \\
\hline $\begin{array}{l}\text { Local } \\
\text { Community }\end{array}$ & Intense & Intense & soft & soft & soft & soft & soft & soft \\
Land & Intense & Intense & & & & & & \\
Crops & Intense & Intense & & & & Intense & Intense \\
Grain & Intense & Intense & & & & Soft & Soft & soft \\
Livestock & Intense & Intense & & & & & & \\
Infrastructure & Intense & Intense & & & & & & \\
\hline
\end{tabular}

Source: Field Survey, 2018

By CBDM Group, the multi-hazards had impacted on local community, land, crops, grain, livestock, and infrastructure. Measurement of its intensity on the above variables was intense (maxima) and soft (minima). Flood and Landslide had an intense impact on all variables: local community, land, crops, grain, livestock, and infrastructure, meanwhile drought and cold wave had also an intense impact on crops. However, hail \& storms, insects, animals, drought, cold waves, and snakes had soft impacts on the local community. Similarly, drought, cold waves, and snakes had a soft impact on livestock. Thus, the study area was flood and landslides-prone areas.

Table 4 shows the result of hazard analysis. The frequency and severity supplemented to flood and landslides.

Table 4: Natural Hazard Analysis

\begin{tabular}{ccccccccc}
\hline Description & Flood & Landslides & $\begin{array}{c}\text { Hail \& } \\
\text { Storm }\end{array}$ & Insect & Animals & Drought & $\begin{array}{c}\text { Cold } \\
\text { wave }\end{array}$ & Snakes \\
\hline Severity & Higher & Higher & Negligible & Negligible & Low & Low & Low & Negligible \\
Frequency & Higher & Higher & Negligible & Negligible & Low & Low & Low & Negligible \\
\hline \multicolumn{2}{l}{ Source: Field Survey, 2018 }
\end{tabular}

Table 5 shows the disaster cycle over a year. It shows the catchment areas: Gadhi, Lekhagaon, and Kunathari having all over years of disasters: flood, landslides, drought, fire, and cold waves. 
Table 5: Disaster Cycle

\begin{tabular}{lllllllllllll}
\hline Description Jan & Feb & Mar & Apr & May & Jun & July & Aug & Sept & Oct & Nov & Dec \\
\hline Flood & & & & & & & & & & \\
Landslides & & & & & & & & & & \\
Drought & & & & & & & & & & \\
Fire & & & & & & & & & & \\
Cold Wave & & & & & & & & & & \\
\hline Source: Field Survey, 2018 & & & & & & & & & & & & \\
\end{tabular}

Thus, the community could identify multi hazards and their risk reduction but the catchment areas: Gadhi, Lekhagaon and Kunathari had multi hazards in which flood and landslides were intense to the community.

5. Results

\subsection{Community Based Disaster Management Group in Community Adaptation Action}

Table 6 presents CBDM Group and action in community adaptation and action in Disaster Management Cycle (Preparedness, Emergency Action, and Recovery and Rehabilitation Plan). There are three queries related to community adaptation and action as follows: a) occurrence of CBDMG's community adaptation and action or not, b) household's participation in CBDMG and c) household's Participation level in CBDMG active participation: full or partial and d) preference of household in disaster from preparedness to recovery.

Table 6: Occurrence of CBDM Group and Action

\begin{tabular}{ccc}
\hline Option & Occurrence of CBDM Group and action (\%) & No. \\
\hline Yes & 97 & 621 \\
No & 3 & 19 \\
\hline Total & 100 & 640 \\
\hline
\end{tabular}

Source: Field Survey, 2018

Table 7: Household's Participation in CBDMG

\begin{tabular}{ccc}
\hline Options & $\begin{array}{c}\text { Household's Participation in CBDM Group for community } \\
\text { Adaptation and action (\%) }\end{array}$ & No. \\
\hline Active & 99 & 634 \\
Passive & 1 & 6 \\
\hline Total & 100 & 640 \\
\hline
\end{tabular}

Source: Field Survey, 2018

Table 8: Household's Participation level in CBDMG

\begin{tabular}{ccc}
\hline Options & $\begin{array}{c}\text { Level Household's Participation in CBDM G in } \\
\text { Community Adaptation and action (\%) }\end{array}$ & No. \\
\hline Full Participation & 80 & 512 \\
Partial Participation & 20 & 28 \\
\hline Total & 100 & 640 \\
\hline
\end{tabular}


Table 7 shows multiple household preferences and choices in three stages of disaster management in CBDMG: a) pre-disaster, b) during the disaster, and c) post-disaster. In the pre-disaster, there are options: a) provide early warning system and disseminate early warning system, b) Evacuate to safer places, c) Raise awareness of disaster prevention, and d) none. The during the disaster, there are options: a) Assist evacuation, b) Participate in the rescue operation, c) Organize and provide necessities at evacuation centers, d) Assist in the relief operation, e) Monitor the situation. In the post-disaster, there are options: a) Repair / reconstruct damaged houses, b) Distribution of relief packages, c) Send goods/disaster assistance to affected people, d) Work together to clean up the environment, e) Mobilize disaster goods and assistance to the community.

Table 9: Priority of CBDMG

\begin{tabular}{llc}
\hline \multicolumn{1}{c}{ Time } & \multicolumn{1}{c}{ Priority of CBDMG on Adaptation Measures } & Percent \\
\hline Before disaster & Provide early warning system and disseminate early warning & 54.5 \\
& Evacuate to safer places & 25 \\
& Raise awareness of disaster prevention & 20 \\
& None & 0.5 \\
\hline $\begin{array}{l}\text { During the } \\
\text { disaster }\end{array}$ & Assist evacuation & 20.8 \\
& Participate in the rescue operation & 40.8 \\
& Organize and provide necessities at evacuation centers & 20.8 \\
& Assist in the relief operation & 10.9 \\
& Monitor the situation & 6.6 \\
\hline After the & Repair / reconstruct damaged houses & 33.3 \\
disaster & Distribution of relief packages & 14.1 \\
& Send goods/disaster assistance to affected people & 48.2 \\
& Work together to clean up the environment & 4.1 \\
\hline
\end{tabular}

Source: Field Survey, 2018

\subsection{Time Allocation and Mobilization o Household to CBDMG's Collective Actions and Its Economic Cost}

Table 10: Time Allocation and Mobilization of Household

\begin{tabular}{|c|c|c|c|c|c|c|c|c|c|}
\hline Time & $\begin{array}{l}\text { Collective } \\
\text { measures of } \\
\text { CBDMG }\end{array}$ & $\begin{array}{c}\text { Mean } \\
\text { man- } \\
\text { hours } \\
\text { per } \\
\text { week }\end{array}$ & $\begin{array}{l}\text { Max } \\
\text { man- } \\
\text { hours } \\
\text { per } \\
\text { week }\end{array}$ & $\begin{array}{c}\text { Mean } \\
\text { man- } \\
\text { hours } \\
\text { per } \\
\text { annum }\end{array}$ & $\begin{array}{l}\text { Max } \\
\text { man- } \\
\text { hours } \\
\text { loss } \\
\text { per } \\
\text { annum }\end{array}$ & $\begin{array}{c}\text { Mean } \\
\text { days } \\
\text { per } \\
\text { annum }\end{array}$ & $\begin{array}{l}\text { Max } \\
\text { days } \\
\text { per } \\
\text { annum }\end{array}$ & $\begin{array}{c}\text { Mean } \\
\text { wage } \\
\text { loss } \\
\text { per } \\
\text { HH } \\
\text { per } \\
\text { annum }\end{array}$ & $\begin{array}{c}\text { Max } \\
\text { wage } \\
\text { loss } \\
\text { per } \\
\text { HH } \\
\text { per } \\
\text { annum }\end{array}$ \\
\hline \multirow[t]{2}{*}{$\begin{array}{l}\text { Before } \\
\text { Hazard }\end{array}$} & $\begin{array}{l}\text { Provide early } \\
\text { warning system } \\
\text { and disseminate } \\
\text { early warning } \\
\text { (committee) }\end{array}$ & 2.5 & 3 & 120 & 144 & 15 & 18 & 7500 & 9000 \\
\hline & $\begin{array}{l}\text { Raise awareness of } \\
\text { disaster prevention }\end{array}$ & 1.5 & 5 & 72 & 240 & 9 & 30 & 4500 & 15000 \\
\hline \multirow{2}{*}{$\begin{array}{l}\text { During } \\
\text { Hazard }\end{array}$} & Assist evacuation & 1.5 & 10 & 72 & 480 & 9 & 60 & 4500 & 30000 \\
\hline & $\begin{array}{l}\text { Monitor } \\
\text { situation }\end{array}$ & 0.5 & 3 & 24 & 144 & 3 & 18 & 1500 & 9000 \\
\hline
\end{tabular}




\begin{tabular}{|c|c|c|c|c|c|c|c|c|c|}
\hline Time & $\begin{array}{l}\text { Collective } \\
\text { measures of } \\
\text { CBDMG }\end{array}$ & $\begin{array}{c}\text { Mean } \\
\text { man- } \\
\text { hours } \\
\text { per } \\
\text { week }\end{array}$ & $\begin{array}{c}\text { Max } \\
\text { man- } \\
\text { hours } \\
\text { per } \\
\text { week }\end{array}$ & $\begin{array}{l}\text { Mean } \\
\text { man- } \\
\text { hours } \\
\text { per } \\
\text { annum }\end{array}$ & $\begin{array}{c}\text { Max } \\
\text { man- } \\
\text { hours } \\
\text { loss } \\
\text { per } \\
\text { annum }\end{array}$ & $\begin{array}{l}\text { Mean } \\
\text { days } \\
\text { per } \\
\text { annum }\end{array}$ & $\begin{array}{l}\text { Max } \\
\text { days } \\
\text { per } \\
\text { annum }\end{array}$ & $\begin{array}{c}\text { Mean } \\
\text { wage } \\
\text { loss } \\
\text { per } \\
\text { HH } \\
\text { per } \\
\text { annum }\end{array}$ & $\begin{array}{c}\text { Max } \\
\text { wage } \\
\text { loss } \\
\text { per } \\
\text { HH } \\
\text { per } \\
\text { annum }\end{array}$ \\
\hline \multirow[t]{5}{*}{$\begin{array}{l}\text { After } \\
\text { Hazard }\end{array}$} & $\begin{array}{l}\text { Work together to } \\
\text { clean up the } \\
\text { environment }\end{array}$ & 2.5 & 5 & 120 & 240 & 15 & 30 & 7500 & 15000 \\
\hline & $\begin{array}{l}\text { Distribution of } \\
\text { relief packages }\end{array}$ & 1 & 2 & 48 & 96 & 6 & 12 & 3000 & 6000 \\
\hline & $\begin{array}{l}\text { Repair } \\
\text { / reconstruct } \\
\text { damaged houses }\end{array}$ & 3 & 6 & 144 & 288 & 18 & 36 & 9000 & 18000 \\
\hline & $\begin{array}{l}\text { Mobilize disaster } \\
\text { goods and } \\
\text { assistance to the } \\
\text { community }\end{array}$ & 0.5 & 1 & 24 & 48 & 3 & 6 & 1500 & 3000 \\
\hline & $\begin{array}{l}\text { Total } \\
\text { In US }(\$) \quad \text { if } \\
1 \$=118\end{array}$ & & & & & 78 & & $\begin{array}{c}39000 \\
330.5\end{array}$ & $\begin{array}{l}105000 \\
889.83\end{array}$ \\
\hline
\end{tabular}

Source: Field Survey, 2018

Table 10 shows time allocation and mobilization of the household to CBDMG's collective action at the community level in three stages of natural hazards: a) before Hazard, b) during hazard and c) after hazard. In another word, these three stages are a) preparedness, b) rescue, and c) recovery and rehabilitation. In the before hazard, the household allocates two options: a) provide an early warning system and disseminate early warning (committee) and b) raise awareness of disaster prevention. Similarly, during hazard, household allocates their time on two options: a) assist evacuation and b) monitor the situation. Furthermore, in the after-hazard, households have four options: a) work together to clean up the environment, b) distribution of relief packages, c) repair/ reconstruct damaged houses, and d) mobilize disaster goods and assistance to the community. In addition, it presents significant values of time allocation of the household to CBDMG in the above different activities in terms of wage. In another word, the household has invisible and unaccounted economic costs to participate, execute and manage CBDMG to be resilient from multi-hazards at the local level.

\section{Discussion}

The above results of descriptive statistics strongly provide evidence of fact and figures related to community-based disaster management group's adaptation and action, collective action of households to satisfy queries: whether the community-based disaster management group's adaptation and action occur, whether households are active to the collective action of the community-based disaster management group coping disaster and disaster management and what is a level of household action in CBDM.

Since disaster is an unpredictable and predictable common issue having undesired negative externality and huge social cost to the community and then households, community-based disaster management group's adaptation, and collective action may be an alternative inevitable measure to cope out disaster by adaptation and mitigation measures to reduce its negative externality and social cost. Therefore, the occurrence of community-based disaster management groups' adaptation and collective action is important. Out of 642 sample households, about 97 percent verified it, despite their vulnerability. Its nature was indigenous and lessons learned at the household level, although the local government was 
active. As collective action, about 99 percent of households endorsed it as their obligatory situation to the community-based disaster management group's collective adaptation. Thus, almost all considered disaster as an unwanted threat to their livelihood, happiness, and welfare. In addition, about 80 percent of the household was fully active meanwhile about 20 percent of the household was partially active. As fourth query: what was the priority of CBDMG on different preferences in different stages of disaster management was employed to ask vulnerable households in the limitation of poverty. Almost all households had two unlimited resources in three catchment areas: Gadhi, Lekhagaon, and Kunathari: leisure time and labor, along with their intuition and indigenous knowledge. Despite two approaches: mitigation and adaptation, the community can think about individual and collective adaptation options and action. So far concerning with community-based disaster management group's adaptation and collective action, there were varieties adaptation options to CBDMG at the community level in three disasters period: a) preparation in the pre-disaster, b) rescue and relief during a disaster, and c) recovery and rehabilitation in the post-disaster. Before the disaster, there were a) provide early warning system and disseminate early warning, b) evacuate to safer places, c) raise awareness of disaster prevention and d) none. During the disaster, there was a) assist evacuation, b) participate in the rescue operation, c) organize and provide necessities at evacuation centers, d) assist in relief operation and e) monitor the situation. After the disaster, there were a) repair /reconstruct damaged houses, b) distribution of relief packages, c) send goods/disaster assistance to affected people, d) work together to clean up the environment, and e) mobilize disaster goods and assistance to the community.

Before the disaster is the preparation period to make disaster resilient to the community. If the preparation is fine, the cost of disaster will be 4 times less than the cost of preparation. Therefore, the implementations of NAPA and LAPA have focused on it. The above results provide evidence that about 54.5 percent of households opined CBDMG preferred early warning system and disseminate early warning option and then after 25 percent household opined CBDMG to help people to evacuation to a safer place and 20 percent household preferred CBDMG on raise awareness about disaster prevention. Behind such households' opinions, choices and preferences, there was theoretical and empirical evidence of the positive correlation between rainfall and disaster (flood and landslides). In addition, the catchment areas: Gadhi, Lekhagaon, and Kunathari VDC are located at different altitudes. If heavy rainfall happens in the upstream catchment area, Gadhi, it will be a sign of flood and landslides in the downstream areas: Lekhagaon and Kunathari. Therefore, early warning system and disseminating early warning option was preferred in disaster preparation. An evacuation plan could be executed on time to save lives and assets by using their awareness about disaster prevention and management. Therefore, almost all household allocated their leisure time 4 hours per week on the above three options in the preparation program activities of CBDMG in the pre-disaster to be disaster resilient and prevention. On raising awareness of disaster prevention, households contributed 5 hours per week on average more than on early warning and information exchange meetings, visiting, and training of CBDMG. Despite zero opportunity cost, households are concerned with uncalculated huge social costs more than the present opportunity cost. However, the social cost to the community was huge in the catchment area.

The disaster period with higher-level risk and threat is the emergency period in which the community had not to have much more time to plan and prepare, except to rescue, evacuate, and relieve. Emergency action is relevant. In the study area, when the flood and landslide disaster were aggressive at the community, the community did emergency action and activities in the support and participation of households in Gadhi, Lekhagaon, and Kunathari. In 2015, the community was active in major three areas: rescue, evacuation, and relief. It was reflected by the household's emergency participation and collective action. Above descriptive statistics provide household's participation in CBDMG's rescue, evacuation, and relief as follows: rescue operation (40.8\%), assist evacuation (20.8\%), 
organize and provide necessities at evacuation centers $(20.8 \%)$, assist in relief operation $(10.9 \%)$ and monitor the situation $(6.6 \%)$. Households' choice and preference in CBDMG was relevant to manage disaster-induced security and humanitarian crisis because this period needed rescue to local people, family, and animals to a safe place and relief to them. In Raksin, Kunathari, a flood entered at midnight. Let's imagine what happened. Similarly, in Gadhi and Lekhagaon, the landslide was at midnight. If rescue and evacuation are not effective, its cost will be more. It depends on the community-based disaster management group's adaption capacity, knowledge, and technology. At the CBDMG level, the household contributed 10 hours per week for evacuation and rescue. Similarly, the household monitored disaster by giving 3 hours per week in CBDMG for alerting the community and also for alternative adaptation strategy at the community level.

After a disaster is the last period of disaster management including reconstruction, recovery, and rehabilitation of individuals and families to return to their normal life and activities. In principle, its reconstruction, recovery, and rehabilitation cost will be more than the cost of preparedness, if preparedness: adaptation capacity, information and infrastructure, rescue, and evacuation are ineffective. Therefore, the effectiveness of preparedness: adaptation capacity, information and infrastructure, and rescue and evacuation during the disaster are must minimize the loss of life and the damage of households. In the catchment areas, the varieties of preparedness programs and activities related to alert systems and awareness were conducted by CBDMG at the community level at different times. How much it was effective is still a query. Household's participation and contribution in CBDMG at the community level reconstruction, recovery, and rehabilitation were to a) work together to clean up the environment $(48.2 \%)$, b) repair /reconstruct damaged houses $(33.3 \%)$, c) distribution of relief packages $(14.1 \%)$, and d) mobilize disaster goods and assistance to the community (4.1\%). In the watershed area, there were four adaptation options in which household had contributed weekly their time in five hours on work together to clean up the environment, two hours on the distribution of relief packages, six hours on repair and reconstructing damaged houses, and one hour to mobilize disaster goods and assistance to the community. Thus, community-based disaster management is a successful module to provide households stakeholders of disaster management with ownership and participation in three disaster stages: before, during, and after the disaster, along with more focus on proactive, preparedness, and participatory activities. It is most effective and efficient in terms of time and resources to minimize natural disaster risk.

No doubt, the above results of CBDMG, show its relevance to being resilient to predicted and unpredicted multi natural hazards. In general, it is assumed that rural households have leisure time without opportunity cost in the absence of a wide, competitive, and heterogeneous labor market and of poor diversification of economic sectors and poor rural and urban labor market linkage and rural households can allocate easily their leisure time on CBDMG for their benefit, interest, and concern. Further, rural households have no choice to join CBDMG in their present vulnerable status. However, time is valuable, and time allocation on CBDMG is an invisible and unaccounted economic cost to households having economic means for rural household income and welfare. In Table 10, the mean per week time allocation of households on CBDMG is invisible and insignificant to households. If you repeat it over a year, the time will be days. It is 78 mean days per household. It is 21 percent of a year (365 days) calendar. Let's suppose the rural wage rate is Rs 500 (4.23 USD), its mean wage income will be 39000 Nepali Rupees (330 USD) per annum that is 30 percent of 1071 USD per capita. Thus, the rural household has a significant economic cost of CBDMG activity to be resilient from multi natural hazards. However, it can reduce multi times the disastrous cost to them. Its outcome may not be positive to household income, welfare, and poverty reduction. 


\section{Conclusion}

This paper analyzes community-based disaster management groups and households' participation in Western Nepal. As a result, about six CBDMG were active in the three catchment villages: Gadhi, Lekhagaon, and Kunathari. In CBDMG, a Non-Government Organization (NGO) had four interventions: a) Community group, b) Awareness \& Sensitization, c) Capacity Building, and d) Tools and Techniques. CBDMG had six major actions: a) Hazard Map, b) Planning, c) Alert System, d) Preventive Construction, e) Awareness Program, and f) Emergency Response and Place. In addition, the community of the catchment areas had the intense impacts of natural hazards: flood and landslide. Their frequency and severity were higher all over the years. Similarly, about 97 percent of households accepted CBDMG's occurrence and activity. In CBDMG, about 99 percent of households participated actively with 80 percent full participation and 20 percent partial participation from pre and post-disaster. CBDMG gave priority firstly on early warning system and disseminate early warning system with 54.5 percent, secondly, on evacuating to safer places with 25 percent, thirdly on raising awareness of disaster prevention and none with 0.5 percent in the pre-disaster. During the disaster, CBDMG preferred firstly on rescue operation with 40.8 percent, secondly on assist evacuation with 20.8 percent, thirdly on assist in relief operation with 10.9 percent, and fourthly on the monitor the situation with 6.6 percent. In the post-disaster, CBDMG preferred firstly on work together with 48.2 percent, secondly on repair/reconstruct damaged houses with 33.3 percent, thirdly on the distribution of relief packages with 14.1 percent, and fourthly on mobilizing disaster goods and assistance to the community with 4.1 percent. Similarly, households had contributed 2 to 4 hours per week in the pre-disaster, 1.5 to 7.5 hours per week during the disaster, and 3.5 to 7 hours per week in the post-disaster. Thus, floods and landslides in the catchment areas: Gadhi, Leckhgaon, and Kunathari are major disasters having an intense, frequent, and wider impact on the vulnerable community for more than four months, along with other natural hazards. In addition, rural household sacrifices 78 mean days per household. It is 21 percent of a year (365 days) calendar. Let's suppose the rural wage rate is Rs 500 (4.23 USD), its mean wage income will be 39000 Nepali Rupees (330 USD) per annum that is 30 percent of 1071 USD per capita. Thus, the rural household has a significant economic cost of CBDMG activity to be resilient from multi natural hazards. Therefore, CBDMG is relevant to make the community stakeholder and owner for their participation disaster management and collective adaptive action for preparedness for minimizing the risk of disaster, along with rescue and recovery but its economic cost should be considered. Therefore, the community-based disaster management group should be made the replicative model to endorse the community as stakeholders for ownership and participation to minimize disaster risk as a spirit of Hyogo Framework for Action (20052015) (2005-2015), IPCC (2001) and Disaster Management Act and Policy 2018 to achieve SDG goals: SDG 1: Poverty, SDG 2: Zero Hunger, SDG 8: Decent Work and Economic Growth, SDG 11: Sustainable Cities and Communities, SDG 13: Climate Action.

\section{References}

Arnstein, S. R. (1969). A ladder of citizen participation. Journal of the American Institute of Planner, 35(4), 216-224

Azad, M.A., Uddin, M.S., Zaman, S., \& Ashraf, M.A., (2019) Community-based Disaster Management and Its Salient Features: A Policy Approach to People-centered Risk Reduction in Bangladesh, Asia-Pacific Journal of Rural Development, 29(2):135-160.

Bista, R.B. (2016). Economics of Nepal. Kathmandu: New Hira Books

Bista, R.B. (2018). Analyzing climate vulnerability in Nepal, the Journal of Economic Concerns, 9 (1): 1-12

Bista, R.B., Dahal, K. \& Gyanwali, R. (2018). A Review of climate change and its effects in the western mountainous water basin of Nepal, Journal of Hydro Nepal, 23: 22-26 
Bista, R.B. (2018). Determinants of flood disaster household's vulnerability in Nepal, Economic Journal of Development Issues, 25 \& 26: 47-59, https://doi.org/10.3126/ejdi.v25i1-2.25093, https://www.nepjol.info > index.php > EJDI

Bista, R.B. (2019). Trend and forecasting analysis on climate variability: a case of Nepal, Journal of Advanced Research in Civil and Environmental Engineering, 6(1): 13-22.

Bista, R.B. (2019). Groping climate vulnerability in western mountainous Nepal: applying climate vulnerability index, Forum for Social Economics, $0(0)$ : 1-19, bttp://:doi.org 10.1080/0760932.2019.1619607.

Bista, R.B. (2019). Index measurement of climate variability and household vulnerability: a case of western Nepal, International Journal of Ecology and Environmental Science. India, 1(1):07-14. www. ecologyjournal.in

Bista, R.B. (2020). Practices and status of preparedness of vulnerable households in disaster management in disaster-prone hill areas of Nepal, Patan Pragya, Nepal. 5(1): 45-52.

CBS (Central Bureau of Statistics) (1991). Population Census 1991. CBS: Kathmandu

District Development Committee (DDC) (2015). District Profile. Surkhet: DDC

Haque, C. E., \& Uddin, M. S. (2013). Disaster management discourse in Bangladesh: A shift from post-event response to the preparedness and mitigation approach through institutional partnerships. In J. Tiefenbacher (Eds.), Approaches to disaster management: Examining the implications of hazards, emergencies, and disasters (pp. 33-44). London: IntechOpen

Huq, S. M. S. (2016) Community-based Disaster Management Strategy in Bangladesh: Present status, prospects, and challenges, European Journal of Research in Social Sciences, 4(2):22-35.

IEDRO (2010). Bangladesh Named Country Most Vulnerable to Natural Disasters, the report. Bangladesh: IEDRO derived from http://iedro.org/articles/bangladesh-named-countrymost-vulnerable-to-natural-disasters/

IPCC(Intergovernmental Panel on Climate Change) (2001). Climate change 2001: Impacts, Adaptation, and Vulnerability, Summary for policymakers, Cambridge: Cambridge University Press.

ISIDRO (International Strategy for Disaster Reduction) (2004). Living with Risk: A Global Review of Disaster Reduction Initiatives. Geneva: ISDRO. http://www.unisdr.org/eng/about isdr/bdlwr-eng.h

Ishiwatari, M. (2012). Chapter 2 Government Roles in Community Based Disaster Risk Reduction. In J. William L. Waugh (Ed.), Community, Environment, and Disaster Risk Management, 10: 1933. UK: Emerald Group Publishing Limited.

Izumi, T., \& Shaw, R. (2012). Effectiveness and challenges for an Asian NGO network for disaster reduction and response. Risk, Hazards 7 Crisis in Public Policy, 2(2), 1-16.

Jahangiri, K., Izadkhah, Y. O., \& Tabibi, S. J. (2011). A comparative study on community-based disaster management in selected countries and designing a model for Iran. Disaster Prevention and Management: An International Journal, 20(1), 82-94.

Khan, M. R., \& Rahman, M. A. (2007). A partnership approach to disaster management in Bangladesh: A critical policy assessment. Natural Hazards, 41(2): 359-378.

Lassa, J., Boli, Y., Nakmofa, Y., Farggide, S., Ofong, A., and Leonis, H. (2018). Twenty years of community-based disaster risk reduction experience from a dryland village in Indonesia, Jamba-Journal of Disaster Risk Studies, 10(1): 1-10.

MoHA (Ministry of Home Affairs)(2020). Disaster Report. Kathmandu: Ministry of Home

MoE (Ministry of Environment), 2020. Koshi Flood Facts. Kathmandu: GON

Oxfam. (2012). Flood preparedness in Viet Nam: A systematic gender-aware approach. Oxford: Oxfam GB

Pandey, B. \& Okazaki, K. (2003). Community-based disaster management: Empowering communities to cope with disaster risks. Japan: United Nations Centre for Regional Development. 
Shaw, R. (2012). Community-based disaster risk reduction. Bingley, UK: Emerald Publisher.

Shaw, R. (2012a). Chapter 1 Overview of Community-Based Disaster Risk Reduction. In J. William L. Waugh (Ed.), Community Environment and Disaster Risk Management, 10: 3-17. UK: Emerald Group Publishing Limited

Sjostedt, F. \& Sturegard, V. (2015). Implementation of Community Based Disaster Risk Management in the Mekong Delta, Vietnam, Report 5022, Sweden: Division of Risk Management and Societal Safety, Lund University.

Slaymaker, T., \& Christiansen, K. (2005). Community-based approaches and service delivery: Issues and options in difficult environments and partnerships. Overseas Development Institute. Retrieved from http://www.odi.org.uk/resources/docs/3822.pdf.

Sterns, N. (2006). The Economics of Climate Change. London: H.M Treasury.

UNEP (2003). Assessing Human Vulnerability to Environmental Change; concepts, issues, methods, and case studies. Nairobi: United Nations Environment Program.

United Nations Framework Conventions on Climate Change (UNFCCC). (2007). Climate change: Impacts, vulnerabilities, and adaptation in developing countries. Bonn: UNFCCC Secretariat.

United Nations Office for Disaster Risk Reduction (UNISDR). (2004). Living with risk: A global review of disaster risk reduction (Vol. 1). New York, NY: United Nations

United Nations International Strategy for Disaster Reduction (UNISDR) (2005). Global assessment report 2005: Making development sustainable: The future of disaster risk management. The Pocket GAR 2005, Geneva: United Nations.

Victoria, L. (2002). Community-based approaches to disaster mitigation. Paper presented at Regional Workshop on Best Practices in Disaster Mitigation, Bangkok.

Victoria, L. P. (2003). Community-based disaster management in the Philippines: Making a difference in people's lives. Philippine Sociological Review, 51: 65-80

Village Development Committee (VDC)(2001). Gadhi Village Development Profile. Gadhi: VDC

World Bank (2016). The press release. Marrakesh: World Bank http://www.worldbank.org/en/news/press-release/2016/11/14/natural-disasters-force26-illion-people-into-poverty-and-cost-520bn-in-losses-every-year-new-world-bankanalysis-finds

Yodmani, S. (2001). Disaster risk management and vulnerability reduction: Protecting the poor. Paper Presented at The Asia and Pacific Forum on Poverty. Asian Disaster Preparedness Centre, Bangkok (pp. vi, 32). Retrieved from http://www.adpc.net/ V2007/IKM/ONLINE\%20DOCUMENTS/downloads/PovertyPaper.pdf 